\title{
RESEARCH
}

Open Access

\section{Gene probing reveals the widespread distribution, diversity and abundance of isoprene-degrading bacteria in the environment}

Ornella Carrión ${ }^{1 *} \mathbb{D}$, Nasmille L. Larke-Mejía ${ }^{1}$, Lisa Gibson ${ }^{1}$, Muhammad Farhan UI Haque ${ }^{1}$, Javier Ramiro-García², Terry J. McGenity ${ }^{3}$ and J. Colin Murrell ${ }^{1 *}$

\begin{abstract}
Background: Approximately $500 \mathrm{Tg}$ of isoprene are emitted to the atmosphere annually, an amount similar to that of methane, and despite its significant effects on the climate, very little is known about the biological degradation of isoprene in the environment. Isolation and characterisation of isoprene degraders at the molecular level has allowed the development of probes targeting isoA encoding the a-subunit of the isoprene monooxygenase. This enzyme belongs to the soluble diiron centre monooxygenase family and catalyses the first step in the isoprene degradation pathway. The use of probes targeting key metabolic genes is a successful approach in molecular ecology to study specific groups of bacteria in complex environments. Here, we developed and tested a novel iso $\mathrm{A}$ PCR primer set to study the distribution, abundance, and diversity of isoprene degraders in a wide range of environments.
\end{abstract}

Results: The new isoA probes specifically amplified isoA genes from taxonomically diverse isoprene-degrading bacteria including members of the genera Rhodococcus, Variovorax, and Sphingopyxis. There was no cross-reactivity with genes encoding related oxygenases from non-isoprene degraders. Sequencing of isoA amplicons from DNA extracted from environmental samples enriched with isoprene revealed that most environments tested harboured a considerable variety of isoA sequences, with poplar leaf enrichments containing more phylogenetically diverse iso $\mathrm{A}$ genes. Quantification by qPCR using these isoA probes revealed that isoprene degraders are widespread in the phyllosphere, terrestrial, freshwater and marine environments. Specifically, soils in the vicinity of high isopreneemitting trees contained the highest number of isoprene-degrading bacteria.

Conclusion: This study provides the molecular ecology tools to broaden our knowledge of the distribution, abundance and diversity of isoprene degraders in the environment, which is a fundamental step necessary to assess the impact that microbes have in mitigating the effects of this important climate-active gas.

Keywords: Isoprene, Climate, Isoprene monooxygenase, isoA, Gene probes

\footnotetext{
* Correspondence: o.carrion-fonseca@uea.ac.uk; j.c.murrell@uea.ac.uk

${ }^{1}$ School of Environmental Sciences, University of East Anglia, Norwich

Research Park, Norwich NR4 7TJ, UK

Full list of author information is available at the end of the article
}

C The Author(s). 2018 Open Access This article is distributed under the terms of the Creative Commons Attribution 4.0 International License (http://creativecommons.org/licenses/by/4.0/), which permits unrestricted use, distribution, and reproduction in any medium, provided you give appropriate credit to the original author(s) and the source, provide a link to the Creative Commons license, and indicate if changes were made. The Creative Commons Public Domain Dedication waiver (http://creativecommons.org/publicdomain/zero/1.0/) applies to the data made available in this article, unless otherwise stated. 


\section{Background}

Isoprene (2-methyl-1, 3-butadiene) comprises approximately one third of the total volatile organic compounds (VOC) emitted to the atmosphere, an amount that is approximately equal to emissions of methane [1, 2]. Although isoprene has a short lifetime in the atmosphere (in the order of hours) due to rapid photochemical oxidation [1], it has a significant impact on atmospheric chemistry and hence climate [3]. In unpolluted environments with low levels of nitrogen oxides, isoprene reacts with hydroxyl radicals, thus reducing the oxidising capacity of the atmosphere [1]. This, in turn, prolongs the lifetime of greenhouse gases such as methane and enhances global warming $[4,5]$. In polluted environments, nitrogen oxides are typically present at high concentrations and react with isoprene, leading to the formation of tropospheric ozone [1], which is a greenhouse gas with important negative effects on plant and animal health [6]. Conversely, atmospheric oxidation of isoprene results in the formation of secondary organic aerosols and cloud condensation nuclei, which in turn promotes global cooling $[7,8]$. The vast majority of isoprene emitted to the atmosphere is produced by terrestrial plants $\left(\sim 500 \mathrm{Tg}\right.$ year $\left.^{-1}\right)[2,9]$, with small contributions from marine algae $\left(0.1-12 \mathrm{Tg}_{\text {year }}{ }^{-1}\right)$ and minor contributions from bacteria, fungi and animals [10-17]. Isoprene is also produced industrially $\left(\sim 0.8 \mathrm{Tg}_{\mathrm{year}}{ }^{-1}\right)$, where it is used primarily to synthesise polyisoprene rubber [18]. In plants, isoprene is synthesised in the chloroplast from dimethylallyl diphosphate (DMAPP), an intermediate of isoprenoid biosynthesis, in a reaction mediated by isoprene synthase [19]. It has been shown that isoprene protects plants against heat and oxidative stress $[9,20]$ and it has also been suggested that it might have a role in plant-insect interactions [21] and plant energy dynamics [22]. However, not all plants produce isoprene, with both high and low emitters being observed even among closely related species [23-25].

Although atmospheric levels of isoprene are low (1$4 \mathrm{ppb}$ ) [26], due to its high reactivity, concentrations are significantly higher (up to $36 \mathrm{ppb}$ ) at ground level in high isoprene-emitting forests [27]. Closed chambers and continuous-flow experiments have shown that soils can act as a biological sink for isoprene at environmentally relevant concentrations [28-30]. These studies confirmed the potential for soil microbes to consume isoprene released locally in soils as well as from the atmosphere. In fact, bacteria that grow on isoprene as sole carbon and energy source have been isolated from soils, leaves and coastal/marine environments [31-37]. These isolates are mainly Actinobacteria, although recently more Alpha- and Betaproteobacteria strains such as Sphingopyxis sp. OPL5 and Variovorax sp. WS11 have also been isolated [38]. All known isoprene degraders contain six genes (isoABCDEF) encoding the isoprene monooxygenase (IsoMO) that catalyses the first step of the isoprene degradation pathway. Four additional genes, isoGHIJ, are located immediately upstream $\left(5^{\prime}\right)$ of the IsoMO structural genes and encode enzymes involved in the subsequent steps in isoprene catabolism [32, 33, 39, 40]. The IsoMO is a four-component soluble diiron monooxygenase (SDIMO) composed of a dimeric hydroxylase, a NAD $(\mathrm{P}) \mathrm{H}$ oxidoreductase, a coupling protein and a Rieske-type ferredoxin. Other members of the SDIMO family include the soluble methane monooxygenase (sMMO), alkene monooxygenases, phenol hydroxylases and aromatic monooxygenases, which are key enzymes in the bacterial oxidation of hydrocarbons and have biotechnological applications [41, 42]. In addition, structural and genetic analyses have revealed that the hydroxylase $\alpha$-subunit of SDIMOs contains a carboxylated-bridge diiron centre in a distinctive 4-helix bundle structure at the active site (reviewed in [42]).

The IsoMO catalyses the initial oxidation of isoprene to 1,2-epoxyisoprene (Fig. 1). The epoxide is converted to 1-hydroxyl-2-glutathionyl-2-methyl-3-butene (HGMB) by a glutathione $S$-transferase (IsoI) and then by a dehydrogenase (IsoH) to 2-glutathionyl-2-methyl-3-butenoate (GMBA) [33]. The fate of GMBA is uncertain. It is assumed that subsequent removal of glutathione and $\beta$-oxidation of these intermediates enable isoprene degraders to grow on isoprene as a carbon source but the final steps in the catabolism of isoprene remain to be elucidated.

The identity and availability of genes essential for isoprene metabolism provide tools for cultivation-independent studies to assess the distribution, diversity and activity of isoprene degraders in the environment. Gene probes are important molecular ecology tools to study functional groups of interest in complex environments. For example, primers targeting genes encoding key subunits of particulate and soluble methane monooxygenase ( $p m o A$ and $m m o X$, respectively) have been used to extend our knowledge of the diversity and abundance of methane-oxidising bacteria in many environments [43-46]. The iso $A$ gene, encoding the $\alpha$-subunit harbouring the active site of IsoMO, is highly conserved in all isoprene degraders studied and is a suitable marker gene for isoprene degradation [36]. Primers targeting iso $A$, tested negative with genes encoding the corresponding active site of SDIMOs from non-isoprene degraders, but amplified iso $A$ from extant isoprene-degrading bacteria and from a range of environmental samples enriched with isoprene, generating sequences which were $>86 \%$ identical to those of bona-fide isoprene degraders [36]. However, the increasing number and variety of isoprene degraders has revealed a higher diversity of iso $A$ sequences, which emphasises the need to refine iso $A$ primers to cover all the isoprene-degrading strains characterised to date. Here, we designed new iso $A$ primers that amplified iso $A$ genes from all extant isoprene 


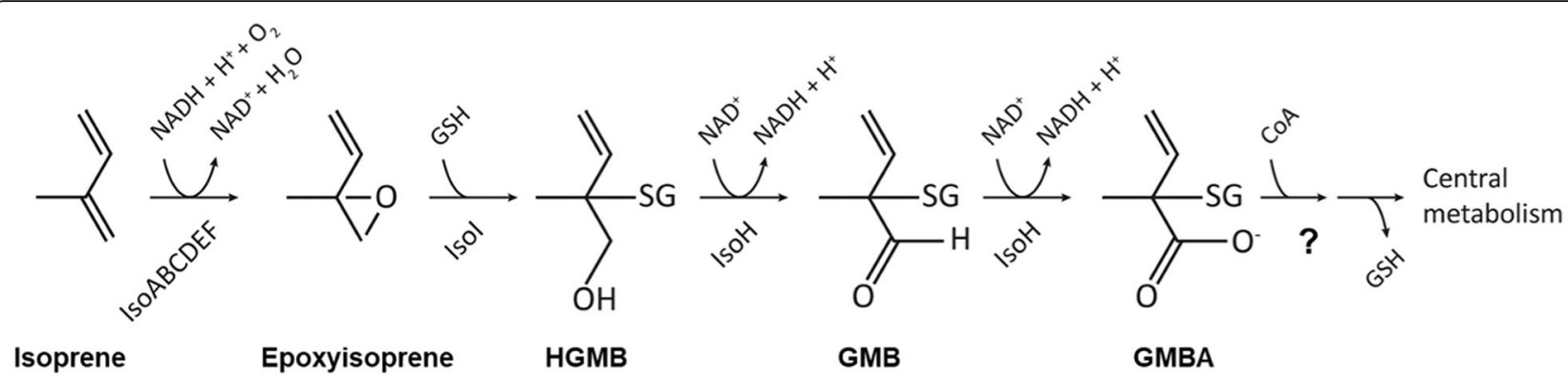

Fig. 1 Isoprene degradation pathway. Enzymes: IsoABCDEF, isoprene monooxygenase; Isol, glutathione-S-transferase; IsoH, dehydrogenase. HGMB 1-hydroxy-2-glutathionyl-2-methyl-3-butene, GMB 2-glutathionyl-2-methyl-3-butenal, GMBA 2-glutathionyl-2-methyl-3-butenoic acid, SG glutathione, GSH reduced glutathione. The question mark indicates uncertainty in the details of the catabolic pathway from GMBA

degraders, but did not amplify isoA homologues of related enzymes from non-isoprene degraders. These new iso $A$ probes were then used to investigate the distribution, diversity and abundance of isoprene degraders in phyllosphere, soils, freshwater and marine environments to better understand their role in the isoprene biogeochemical cycle.

\section{Results and discussion}

\section{Design and validation of isoA primers}

In order to cover the diversity of all well-characterised isoprene degraders, we designed new probes targeting iso $A$, as this gene encodes the $\alpha$-subunit containing the active site of the IsoMO and is an excellent marker gene for isoprene degradation [36]. We aligned the iso $A$ genes from 38 bona-fide isoprene degraders available from Genbank and strains recently isolated by our group (Additional file 1: Table S1). Microorganisms included in the analysis belonged to the classes Actinobacteria (e.g. Gordonia, Mycobacterium, Rhodococcus), Alphaproteobacteria (e.g. Sphingopyxis) and Betaproteobacteria (e.g. Variovorax). Eighteen isoA sequences detected in the metagenomes from isoprene enrichments of willow soil, willow leaves and poplar leaves (unpublished data) were added to the iso $A$ database to design the new probes. These metagenome-derived sequences had a minimum query coverage of $98 \%$ and an identity of $\geq 85 \%$ at the derived amino acid level to ratified IsoA sequences. Finally, genes encoding the $\alpha$-subunit of other SDIMOs such as sMMO, alkene monooxygenase or toluene monooxygenase from non-isoprene-degrading microorganisms (Additional file 1: Table S1) were also included in the alignment to guide the specific amplification of $i s O A$ genes by the new probes. Conserved positions within the isoA gene were identified and various sets of primers spanning different regions were manually designed (Additional file 1: Table S2; Figure S1). Eleven different combinations of primers were initially tested (Additional file 1: Table S3), including isoA14F and isoA1019R, which have been previously investigated [38]. In this preliminary validation of the iso $A$ probes, Rhodococcus sp. AD45 and Variovorax sp.
WS9 were selected as representative Gram-positive and Gram-negative isoprene-degrading bacteria. Xanthobacter autotrophicus Py2 was chosen as a negative control since the $\alpha$-subunit of its alkene monooxygenase is closely related to IsoA (70\% amino acid identity to IsoA from Rhodococcus sp. AD45).

Five out of the 11 combinations of primers tested yielded a PCR product of the expected size from the positive control strains, but there was no amplification from Xanthobacter autotrophicus Py2 (Additional file 1: Figure S2). Combinations isoA136F + isoA1019R, isoA300F + isoA1019R, isoA379F + isoA862R and isoA379F + isoA1019R also generated non-specific amplification products (Additional file 1: Figure S2). However, the combination of primers isoA14F and isoA511R, which spans the first iron centre of the IsoMO $\alpha$-subunit (Additional file 1: Figure S1), yielded a specific PCR product of $497 \mathrm{bp}$. Therefore, we selected primers isoA14F and isoA511R for further validation on genomic DNA from additional isoprene-degrading and non-degrading isolates (Additional file 1: Table S4). A specific amplification product of the expected size was obtained for all 30 positive control strains used in this study. To check the cross-reactivity of the primers isoA14F and isoA511R, we used as negative controls 12 non-isoprene-utilising strains with related oxygenases to IsoMO that grow on alkanes, alkenes or aromatic compounds. Examples include bacteria containing sMMO (Methylococcus capsulatus Bath), toluene monooxygenase (Pseudomonas mendocina KR1) or alkene monooxygenase (Rhodococcus rhodochrous B276). We also studied as negative controls two strains that belong to the same genera as the bona-fide isoprene degraders Rhodococcus (Rhodococcus opacus DSM 1069) and Variovorax (Variovorax paradoxus EPS), but do not oxidise isoprene (Additional file 1: Table S4). No PCR products were obtained with the primers isoA14F and isoA511R with template DNA from any of the negative control strains. To check that the lack of amplification was not due to the quality of the DNA, a 16S rRNA gene PCR was performed and strong amplification products were obtained with DNA from all 14 negative control strains 
(data not shown). Therefore, we conclude that the primers isoA14F and isoA511R are specific for iso $A$ encoding the $\alpha$-subunit of the IsoMO and ratify that iso $A$ is an excellent marker gene to determine if isoprene-degrading bacteria contain IsoMO.

\section{Diversity of iso $A$ genes in environmental samples}

To test the specificity of the new isoA primer set and to investigate the diversity of iso $A$ genes, and thus isoprene degraders in various environments, we enriched 11 samples from phyllosphere, soils, freshwater and marine environments with isoprene (Additional file 1: Table S5). DNA extracted from these enrichments was subjected to PCR amplification with the isoA primer set isoA14F and isoA511R. A single PCR product of the correct size (497 bp) was obtained with all the enrichments. To confirm that these PCR products contained only iso $A$ genes, before committing to high-throughput sequencing of iso $A$ amplicons, 9 out of the 11 enriched environmental samples were selected to construct isoA libraries from purified PCR amplicons. Sixty-nine clones from these iso $A$ libraries were sequenced (Additional file 1: Table S5). Bioinformatic analysis using BLASTx [47] confirmed all sequences as iso $A$ genes as they had an identity of $84-100 \%$ at the derived amino acid level to IsoA from bona-fide isoprene degraders and were $\leq 70 \%$ identical to other $\alpha$-subunits of closely related SDIMOs that are not IsoMO such as the alkene monooxygenase from Xanthobacter autotrophicus Py2.

The diversity of isoA sequences in DNA extracted from enriched samples from leaves varied according to the type of tree sampled. For example, iso $A$ genes from ash leaf enrichments were similar to $i s o A$ from Rhodococcus, whereas iso $A$ genes from oil palm leaf samples were phylogenetically close to isoA from Gordonia (Fig. 2). It was not surprising to find Rhodococcus isoA homologues in leaf enrichments, as several isoprene-degrading bacteria from this genus have been obtained from poplar, willow, oil palm and horse chestnut leaves [35, 36, 38]. In addition, Gordonia strains able to grow on isoprene have been previously isolated from an estuarine environment and oil palm leaves [31, 38].

Most of the isoA sequences retrieved from soils were phylogenetically close to isoA from Variovorax, although Rhodococcus isoA homologues were also found in DNA from tyre dump soil enrichments (i.e. tyre dump soil clone 14; Fig. 2). Variovorax strains are common inhabitants of soil and water [48-50], and are frequently associated with the phyllosphere $[51,52]$ and rhizosphere $[53,54]$ of plants. Indeed, some species of this genus, such as Variovorax paradoxus, are considered plant growth-promoting rhizobacteria that exert beneficial effects on plant growth [54]. Variovorax species are metabolically versatile bacteria that can degrade a wide range of natural and xenobiotic compounds such as alkanesulfonates, polychlorinated biphenyls or trichloroethylene [55]. Larke-Mejía [38] has shown that two novel Variovorax strains, isolated from soil surrounding a willow tree can grow on isoprene. The presence of Rhodococcus isoA homologues in soil collected from a tyre dump site is consistent with the recent isolation of isoprene-degrading Rhodococcus strains from these samples [38].

In freshwater sediment enrichments, the predominant iso $A$ sequences were phylogenetically closer to $i s o A$ from Rhodococcus, though sequences similar to iso $A$ from Sphingopyxis were also present (i.e. freshwater sediment clone 5; Fig. 2). In fact, Rhodococcus sp. AD45, the most well-characterised isoprene degrader, was isolated from freshwater sediment [32]. Sphingopyxis is a genus commonly associated with the phyllosphere [51, 52], although Sphingopyxis species have also been isolated from soils, freshwater and seawater samples [56-59]. It was not until the isolation of Sphingopyxis sp. OPL5 [38], however, that members of this genus were shown to metabolise isoprene.

Finally, in salt marsh sediment enrichments, only iso $A$ sequences from Rhodococcus were found, whereas enrichments with coastal sediment yielded more diverse isoA sequences, with both Rhodococcus and Variovorax iso $A$-like genes being obtained from the clone libraries (i.e. coastal sediment clones 4 and 5; Fig. 2). Indeed, the presence of Rhodococcus isoA homologues in marine environments has been confirmed with the recent isolation of two isoprene-degrading Rhodococcus strains from salt marsh and coastal sediments (unpublished data).

Since the sequences obtained from the clone libraries were specific to iso $A$ and showed variability within and across the different ecosystems studied, we explored in more detail the diversity of iso $A$ genes in the environment using high-throughput sequencing. Purified isoA PCR products from DNA isolated from 11 enriched environmental samples were sequenced using Illumina MiSeq technology (Additional file 1: Table S5). isoA amplicon sequencing yielded a total of 136,986 quality-filtered sequences with an average of 12,453 reads per sample. These iso $A$ sequences, when analysed by the DADA2 pipeline [60], grouped into 136 unique operational taxonomic units (OTUs) that were manually checked by BLASTx (see Methods). Two OTUs, representing 0.3\% and $2.5 \%$ of the sequences from DNA extracted from enriched poplar leaves and freshwater sediment, respectively, were discarded for the analysis as they had hits to proteins not related to IsoA or other SDIMO $\alpha$-subunits. Therefore, a final set of 134 OTUs was used for downstream analysis (Fig. 3; Additional file 2: Table S6).

The iso $A$ amplicon sequencing analysis revealed that the phyllosphere yielded most variability between samples when compared to other environments (Fig. 3). For example, 99.8\% of the iso $A$ sequences from ash leaf enrichments were 


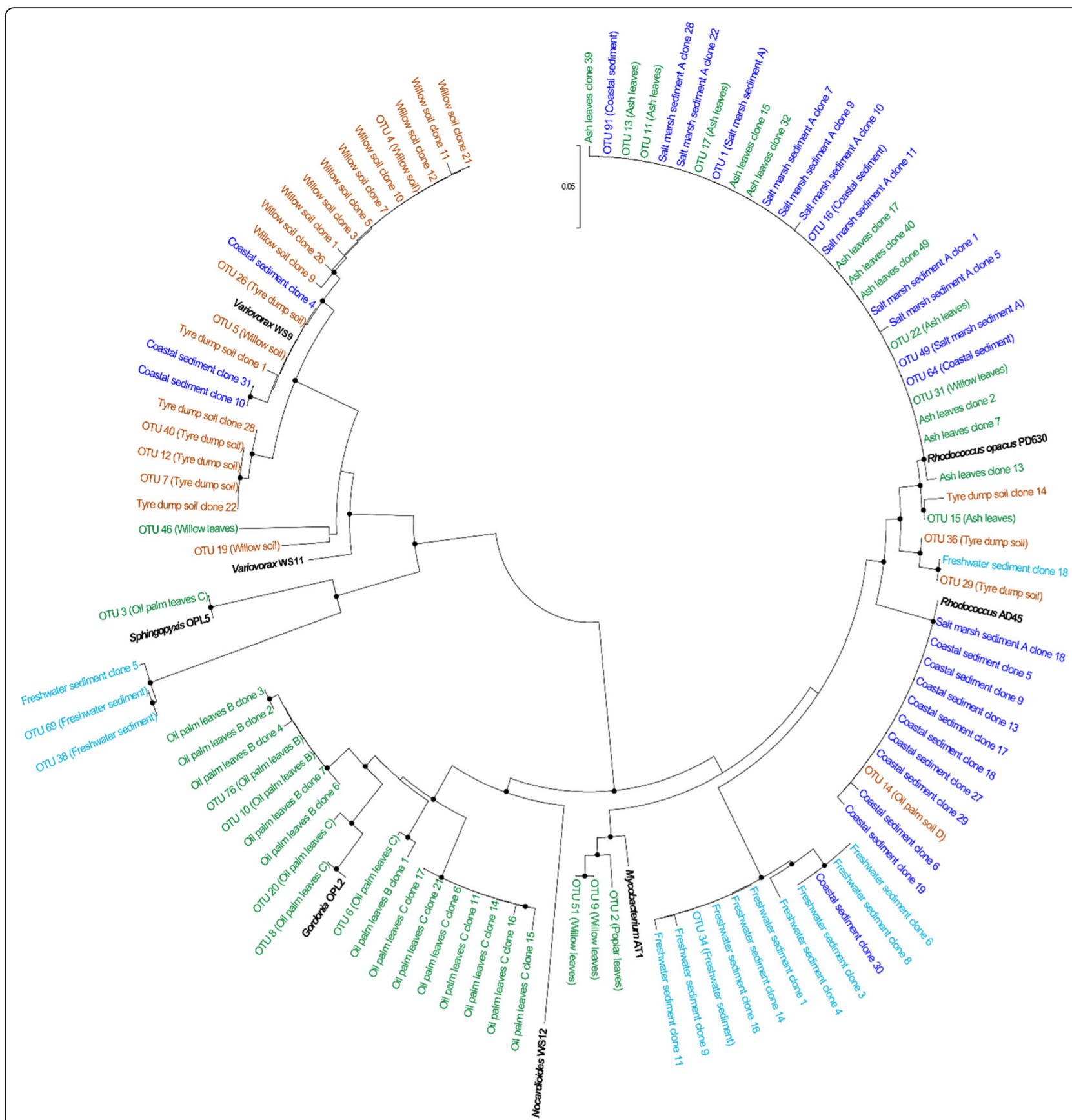

Fig. 2 Phylogenetic tree of IsoA sequences retrieved from enriched environmental samples. Sequences in black represent IsoA sequences from bona-fide isoprene degraders. Sequences obtained from clone libraries and amplicon sequencing of leaf samples are represented in green, soils in brown, freshwater environments in light blue and marine sediments in dark blue. Environments where a particular OTU is abundant are shown in brackets. Only OTUs with $\geq 2 \%$ abundance in at least one of the samples are represented. The tree was drawn in Mega7 [82] using the neighbour-joining method and the Jones-Taylor-Thornton model. Scale bar indicates 0.05 substitutions per site. Bootstrap values $\geq 50 \%$ (based on 1000 replicates) are represented with dots at branch points

similar to isoA from Rhodococcus. isoA genes similar to those of Gordonia and Mycobacterium were also found, although at low relative abundance $(<1 \%)$. Conversely, DNA from oil palm leaf enrichments yielded predominantly Gordonia and Sphingopyxis iso $A$ homologues, even though iso $A$ genes from
Rhodococcus and Mycobacterium were also present $(<1 \%)$. Indeed, we have recently isolated isoprene-degrading Gordonia and Sphingopyxis strains from oil palm leaves [38]. The predominant sequences in willow leaf enrichments were phylogenetically close to isoA from Mycobacterium (50.7\%) 


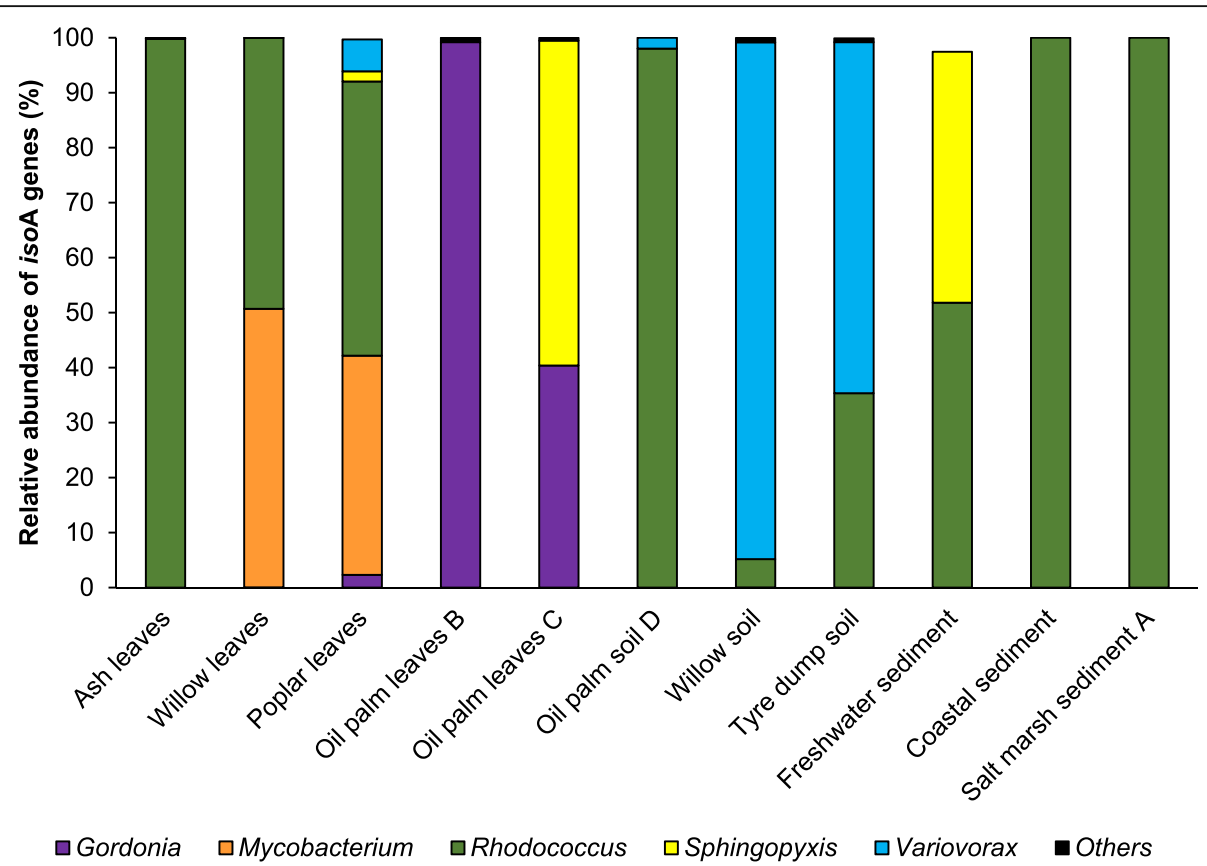

Fig. 3 Relative abundance and diversity of iso $A$ genes in enriched environmental samples revealed by amplicon sequencing. iso $A$ amplicon yielded an average of 12,453 quality-filtered reads per sample. After analysis with the DADA2 pipeline [60] a final set of 134 unique OTUs was obtained (Additional file 2: Table S6). Only OTUs with $\geq 1 \%$ abundance in at least one of the samples are represented. For relative abundance of individual OTUs in each enriched environmental sample, see Additional file 1: Figure S3. For a-diversity of enriched environmental samples estimated using Shannon index, see Additional file 1: Table S7

and Rhodoccocus (49.3\%). Finally, poplar leaf enrichments yielded more phylogenetically diverse iso $A$ genes, with homologues to isoA from Gordonia (2.3\%), Mycobacterium (40\%), Rhodococcus (50\%), Sphingopyxis (1.9\%), and Variovorax $(5.8 \%$, Fig. 3). Although these genera are common inhabitants of the phyllosphere and soils [50, 51, 54, 61], no Variovorax or Mycobacterium strains from leaves able to metabolise isoprene have been reported so far.

The most abundant iso $A$ sequences identified in willow, oil palm and tyre dump soil enrichments were similar to Rhodococcus and Variovorax isoA genes (Fig. 3). isoA sequences from Mycobacterium, Nocardioides and Sphingopyxis were also detected in willow soil $(<1 \%)$. Sequences similar to isoA from Gordonia, Mycobacterium and Sphingopyxis were present at low relative abundance $(<1 \%)$ in DNA extracted from tyre dump soil. These results are consistent with the isolation of Nocardioides, Rhodococcus and Variovorax isoprene-degrading strains from willow and tyre dump soils [35, 38].

Finally, iso $A$ homologues from Sphingopyxis (46.8\%) and Rhodococcus (53.2\%) dominated DNA from freshwater sediment enrichments, whereas iso $A$ sequences retrieved from coastal and salt marsh enriched samples had highest identity to isoA from Rhodococcus (Fig. 3).

In addition, several sequences were distinct from those of iso $A$ of bona-fide isoprene degraders, indicating that there is likely novel diversity of isoprene-utilising bacteria yet to be discovered. For example, most of the iso $A$ clones and OTUs originating from enriched freshwater sediment samples (i.e. freshwater sediment clones 5 and 8; OTUs 34 and 38) occupied a distinct position in the IsoA phylogenetic tree as shown in Fig. 2. BLASTx analysis of these sequences revealed that they had $83-91 \%$ identity at the derived amino acid level to IsoA from extant isoprene degraders of the genera Rhodococcus and Sphingopyxis, suggesting that this environment harbours novel isoprene-utilising strains. The sequencing information obtained using the new iso $A$ probes isoA14F and isoA511R can now be used to design targeted enrichment and isolation strategies to isolate novel species of isoprene degraders from various environments and expand the diversity of existent isoprene-degrading bacteria.

\section{Distribution and abundance of isoprene degraders in the environment}

iso $A$ primer set isoA14F and isoA511R was used to study the distribution and abundance of $i s o A$-containing bacteria using qPCR. iso $A$ primers were first optimised and validated on DNA extracted from environmental samples enriched with isoprene (Additional file 1: Figure S5). Subsequently, clone libraries from qPCR products obtained from both enriched and natural (non-enriched) environmental samples were constructed to ensure that iso $A$ qPCR products were absolutely specific for iso $A$. Fifty-two 
clones from these iso $A$ libraries were sequenced. All sequences had $89-100 \%$ identity at the derived amino acid level to IsoA from bona-fide isoprene degraders and were $\leq 70 \%$ identical to other $\alpha$-subunits of closely related SDIMOs that are not IsoMO such as the alkene monooxygenase from Xanthobacter autotrophicus Py2.

After qPCR assay validation, the abundance of isoprene degraders across a wide range of natural samples, including leaves, soils, freshwater and marine sediments was studied. Interestingly, leaves from high isoprene-emitting trees such as willow, poplar and oil palm [62, 63] contained similar iso $A$ numbers as those from an ash tree, a low isoprene emitter (between $11.6 \pm 3.6$ and $23.7 \pm 6.1$ iso $A$ genes per million copies of $16 \mathrm{~S}$ rRNA gene in DNA extracted from high isoprene-emitting trees, versus $22.4 \pm$ 5.6 iso $A$ genes per million copies of $16 \mathrm{~S}$ rRNA gene in DNA from ash leaves; Fig. 4). However, a larger number of environmental samples will be required to confirm statistically that there are no significant differences in the abundance of isoprene degraders between high and low-emitting trees. Moreover, soils sampled in the vicinity of high isoprene-emitting trees yielded the highest numbers of isoprene degraders (with values ranging from $122.2 \pm 5.0$ to $303.3 \pm 60.3$ iso $A$ genes per million copies of $16 \mathrm{~S}$ rRNA gene; Fig. 4). The fact that there were 10-fold more isoprene degraders in soils than in the leaves of the same trees could be explained by the flux of bacteria from the phyllosphere to the pedosphere during rainfall, which has been estimated to be up to $1.5 \times 10^{16}$ cells ha $^{-1}$ year $^{-1}$ in a subtropical oak-cedar forest [64]. It was not surprising to see relatively high numbers of iso $A$ genes $(67.7 \pm 14.4$ iso $A$ genes per million copies of 16S rRNA gene) in soil sampled from a tyre dump, since tyres mainly consist of polyisoprene rubber $[65,66]$. Although several bacteria and fungi can degrade polyisoprene rubber [67, 68], some studies have suggested that actinomycetes are the key microorganisms carrying out this process [69-72]. The cleavage of polyisoprene rubber by Lcp and RoxA oxygenases results in the production of oligoisoprene molecules [73] that could potentially be used by the isoprene degraders for growth. Indeed, rubber-contaminated soils have yielded isoprene-utilising bacteria from different genera, including Rhodococcus [38, 74], although these strains were not characterised in detail. Grassland and landfill soils also contained isoprene degraders, although at lower relative abundance (from $12.4 \pm 1.3$ to $25.4 \pm 2.8$ iso $A$ genes per million copies of $16 \mathrm{~S}$ rRNA gene) than soils surrounded by high isoprene-emitting trees, as anticipated (Fig. 4). The presence of isoprene-degrading microorganisms was also studied in freshwater and marine natural samples. Surprisingly, these samples yielded similar copy numbers of $i s o A$ genes (ranging from $12.0 \pm 1.9$ to $25.1 \pm$ 2.8 iso $A$ copies per million copies of $16 \mathrm{~S}$ rRNA gene) as leaves (Fig. 4). This was unexpected since isoprene emissions from marine environments $\left(0.1-12 \mathrm{Tg}\right.$ year $\left.^{-1}\right)[2,11$, 16] are very much lower than from terrestrial plants $\left(500 \mathrm{Tg} \mathrm{year}^{-1}\right)[2,9]$. In marine environments, isoprene is synthesised by phytoplankton, heterotrophic bacteria and seaweeds [16]. However, only a few studies have directly measured the isoprene concentration in the euphotic zones of the oceans and the exact mechanism behind marine isoprene production is still unknown [75]. Another

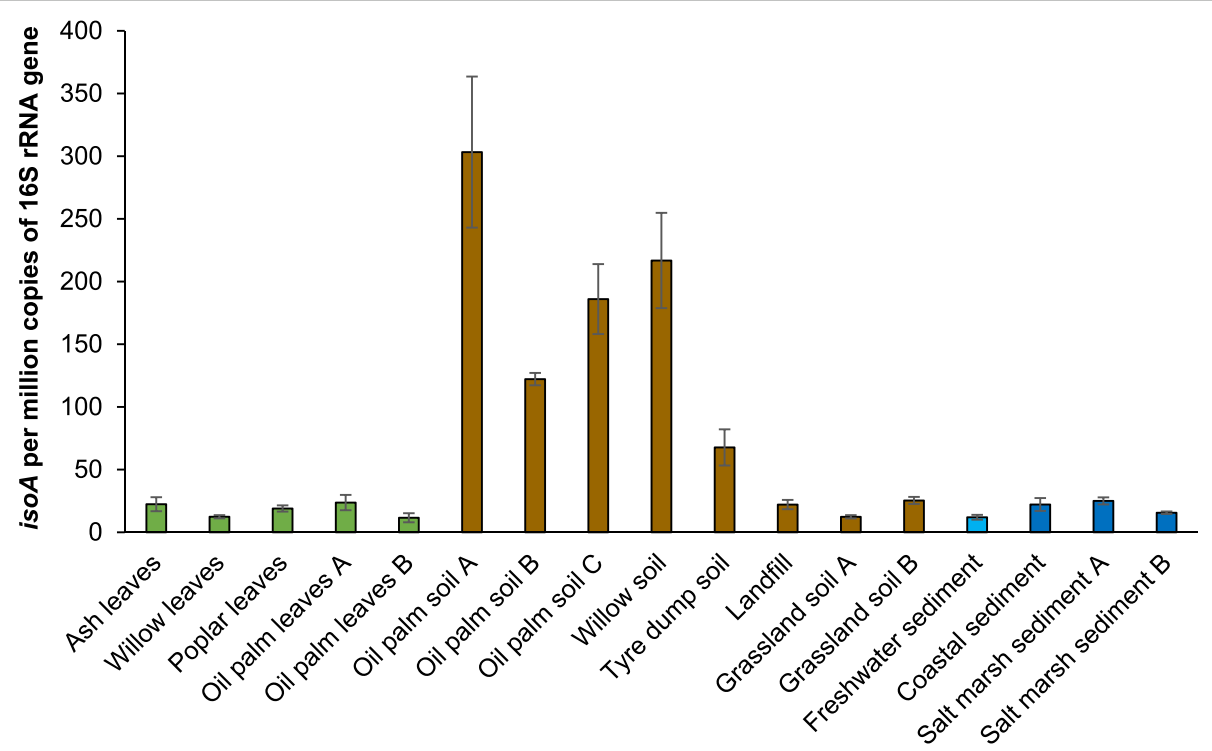

Fig. 4 Relative abundance of isoprene degraders in natural (non-enriched) environmental samples estimated by qPCR. isoA copies are normalised to the 165 rRNA gene copy number in each sample. Results shown are the average of triplicate samples. Error bars represent standard deviations. Leaf samples are represented in green, soils in brown, freshwater environments in light blue and marine sediments in dark blue 
poorly understood aspect of the marine isoprene cycle is the role of microbial degradation. Ocean depth profiles of isoprene concentrations have suggested that isoprene is biologically consumed [75-78]. Indeed, Acuña Alvarez et al. [31] and Johnston et al. [37] found isoprene-degrading bacteria in estuarine and marine water samples, most of which were Actinobacteria. More importantly, Acuña Alvarez et al. [31] also showed that isoprene-utilising bacteria degraded isoprene from the headspace of microalgae cultures at environmentally relevant concentrations. A recent study by Steinke et al. [17] has reported that freshwater lakes also emit isoprene to the atmosphere. Therefore, additional laboratory experiments and field studies as well as more accurate models are required to better understand the isoprene cycle in marine and freshwater environments.

\section{Conclusions}

Although we cannot exclude the possibility that iso $A$ genes from novel uncultivated isoprene-degrading bacteria have been missed, or that other pathways of isoprene metabolism exist, new probes targeting the iso $A$ gene encoding the active site of the IsoMO have proven to be a successful tool to study the diversity, distribution and abundance of isoprene degraders in a wide range of environments. This now facilitates the development of targeted strategies to isolate novel genera of isoprene degraders, monitor them under natural conditions and to determine how isoprene degradation is regulated in the environment. This study provides molecular probes to investigate the significance of the isoprene biological sink and how bacteria might mitigate the effect on the atmosphere of this abundant climate-active gas.

\section{Methods}

\section{Enrichments of environmental samples with isoprene}

To study the distribution, abundance and diversity of isoprene degraders in the environment, a wide range of terrestrial, phyllosphere, freshwater and marine samples were collected (Additional file 1: Table S5). Terrestrial samples comprised soils from the vicinity of high isoprene-emitting trees (oil palm and willow) and soils without nearby high isoprene-emitting vegetation (grassland and landfill soils). Soil from a tyre dump was also studied since several isoprene-degrading strains have been isolated from rubber-contaminated soils [38, 74]. Samples from the phyllosphere included leaves from high isoprene-producing trees as for example, willow, poplar and oil palm, and low emitters such as ash trees. Freshwater samples were collected from a local lake. Samples from marine environments consisted of coastal and salt marsh sediments (Additional file 1: Table S5).

In the case of soils, freshwater and marine sediments, only the top $3 \mathrm{~cm}$ were collected after removing vegetation or macroscopic algae. Further, $1 \mathrm{~g}$ of material was used to set up microcosm enrichments in $120 \mathrm{ml}$ sealed vials containing $10 \mathrm{ml}$ of water for soils, Ewers medium [79] for freshwater sediments or marine basal medium (MBM) [80] for marine samples. Salinity of MBM was adjusted to 20 practical salinity units (PSU) in coastal sediment samples and to 35 PSU in salt marsh sediments to mimic natural conditions.

The surface of 3-10 leaves from each tree (depending on leaf size) was sampled by washing leaves with Ewers medium or using cotton swabs. For leaf washings, leaves were immersed in $50 \mathrm{ml}$ of Ewers medium in $250 \mathrm{ml}$ conical flasks and submerged in a water bath for sonication ( $5 \mathrm{~min}, 50 \mathrm{kHz}$; Mettler ME2), followed by shaking on an orbital shaker $(1 \mathrm{~h}, 150 \mathrm{rpm})$ to detach microbial cells from the surface of the leaves. Leaves were then removed from the flasks and medium was centrifuged $(5000 \times g, 20 \mathrm{~min})$ to separate cells and particulate material from the supernatant. Supernatant was filtered through CellTrap CT402LL001N00 filters (Mem-Teq). Pellets of cells and particulate material were combined with the filtrated supernatant, resuspended in $10 \mathrm{ml}$ of fresh minimal medium and transferred to $120 \mathrm{ml}$ sealed vials. When leaf surfaces were sampled with cotton swabs (ash leaves and oil palm leaves $\mathrm{C}$ ), the swabs were placed in $250 \mathrm{ml}$ conical flasks containing $50 \mathrm{ml}$ of Ewers medium and sonicated in a water bath as above. After shaking in an orbital shaker for $1 \mathrm{~h}$ at $150 \mathrm{rpm}$, cotton swabs were removed and medium was aliquoted into $120 \mathrm{ml}$ sealed vials.

All enrichments were set up in triplicate and incubated at $25^{\circ} \mathrm{C}$ with $25 \mathrm{ppm}$ isoprene, except for oil palm leaf samples from Malaysia, which were incubated at $30{ }^{\circ} \mathrm{C}$ with $50 \mathrm{ppm}$ of isoprene. Consumption of isoprene was monitored daily by gas-chromatography as described in [34]. When isoprene was depleted in the headspace, samples were spiked again with $25 \mathrm{ppm}$ of isoprene or $50 \mathrm{ppm}$ in the case of oil palm leaf samples from Malaysia. Enrichments were subcultured at 2-week intervals three times by making $1 / 10$ dilutions of the samples in fresh medium.

\section{DNA extraction from bacterial strains and environmental samples}

Genomic DNA from positive and negative control strains was extracted from cultures grown in rich media using the Wizard Genomic DNA Purification Kit (Promega), according to the manufacturer's instructions.

To extract DNA from environmental samples, the Fas$\mathrm{tDNA}^{\mathrm{sm}}$ SPIN kit for Soil (MP Biomedicals) was used following the protocol described by the manufacturer.

\section{Amplification of iso $A$ genes}

Fifty nanograms of genomic DNA or $20 \mathrm{ng}$ to $1 \mu \mathrm{g}$ of environmental DNA were used as a template in a $50 \mu \mathrm{l}$ 
PCR reaction containing $4 \mu \mathrm{M}$ of isoA14F (5'-GVGACG AYTGGTAYGACA-3') and isoA511R (5'-TCGT CRAAGAARTTCTTBAC-3') primers. The PCR program consisted of an initial step of $94{ }^{\circ} \mathrm{C}$ for $2 \mathrm{~min}$, followed by 31 cycles of $95{ }^{\circ} \mathrm{C}$ for $15 \mathrm{~s}, 54{ }^{\circ} \mathrm{C}$ for $30 \mathrm{~s}$, $72{ }^{\circ} \mathrm{C}$ for $1 \mathrm{~min}$ and a final extension step of $72{ }^{\circ} \mathrm{C}$ for $7 \mathrm{~min}$. In the case of freshwater and marine DNA samples, 40 cycles were carried out to obtain an amplicon visible on an agarose gel stained with ethidium bromide.

\section{Clone libraries}

isoA PCR products from environmental samples were purified using the NucleoSpin gel and PCR Clean-up kit (Macherey-Nagel) and cloned into the pGEM ${ }^{\circ}-\mathrm{T}$ easy vector system (Promega) following the manufacturer's instructions prior to transformation into Escherichia coli TOP10 cells. Positive clones were screened by PCR using the M13F and M13R primers. Clones yielding a PCR product were sent for sequencing using M13 primers.

\section{iso $A$ amplicon sequencing}

Duplicate PCR products from each environmental sample were pooled before DNA purification using the NucleoSpin gel and PCR Clean-up kit (Macherey-Nagel). The quality of DNA was assessed by gel electrophoresis and the Qubit dsDNA High Sensitivity Assay Kit (ThermoFisher) according to the manufacturer's instructions. Purified iso $A$ amplicons from enriched environmental samples were subjected to Illumina Mi-Seq sequencing by MrDNA (Shallowater, TX, USA) using an Illumina MiSeq platform.

iso $A$ amplicon sequencing data were analysed using DADA2 pipeline [60] with default filtering parameters. Reads were truncated at 275 nucleotides and quality-filtered if their expected error was higher than two. After denoising the sequences using the estimated error rates, forward and reverse reads were merged. Resultant sequences were screened for chimeras and then manually checked by BLASTx [47]. Those OTUs with a top hit distinct from a ratified IsoA sequence were discarded, obtaining a final set of 134 unique OTUs for downstream analysis.

\section{Quantitative real-time PCR}

Quantification of isoprene degraders in environmental samples was estimated by qPCR targeting the iso $A$ gene using primers isoA14F and isoA511R (Additional file 1: Table S2). qPCR assays were carried out using a StepOne Plus real-time PCR instrument (Applied Biosystems). qPCR reactions $(20 \mu \mathrm{l})$ contained 2-20 ng of DNA, $400 \mathrm{nM}$ of each primer and $10 \mu \mathrm{l}$ of SensiFast SYBR Hi-ROX kit (Bioline). The qPCR reaction consisted of an initial denaturation step at $95^{\circ} \mathrm{C}$ for $3 \mathrm{~min}$, followed by 40 cycles of $95{ }^{\circ} \mathrm{C}$ for $20 \mathrm{~s}$, $60{ }^{\circ} \mathrm{C}$ for $20 \mathrm{~s}$ and $72{ }^{\circ} \mathrm{C}$ for $30 \mathrm{~s}$. Data were acquired at $88^{\circ} \mathrm{C}$ for $15 \mathrm{~s}$ to avoid quantification of primer dimers. Specificity of qPCR reactions was determined from melting curves obtained by increasing the temperature in $0.3{ }^{\circ} \mathrm{C}$ increments from 60 to $95{ }^{\circ} \mathrm{C}$, followed by gel electrophoresis and clone library construction from several qPCR products.

The copy number of iso $A$ genes was determined from qPCR of ten-fold dilution series $\left(10^{0}-10^{8}\right.$ copies per $\left.\mu \mathrm{l}\right)$ of DNA standards (Additional file 1: Figure S4). Standards were prepared by cloning the isoA gene of Rhodococcus sp. AD45 into the pGEM ${ }^{\circ} \mathrm{T}$ Easy vector (Promega) and using this as template DNA. The detection limit of the iso $A$ qPCR assay was $10^{2}$ copies per $20 \mu$ reaction.

Finally, iso $A$ copies were normalised to $16 \mathrm{~S}$ rRNA gene copy number in order to estimate the abundance of isoprene degraders in different environmental samples.

Number of copies of 16S rRNA genes was determined by qPCR using 519F and 907R primers [81]. Reactions $(20 \mu \mathrm{l})$ contained 10-70 pg DNA, $400 \mathrm{nM}$ of each primer and $10 \mu \mathrm{l}$ of SensiFast SYBR Hi-ROX kit. The qPCR reaction consisted of an initial denaturation step at $95^{\circ} \mathrm{C}$ for $3 \mathrm{~min}$, followed by 40 cycles of $95{ }^{\circ} \mathrm{C}$ for $20 \mathrm{~s}, 55^{\circ} \mathrm{C}$ for $20 \mathrm{~s}$ and $72{ }^{\circ} \mathrm{C}$ for $30 \mathrm{~s}$. Data collection was performed at $72{ }^{\circ} \mathrm{C}$ for $15 \mathrm{~s}$. Specificity of the qPCR reaction and quantification of $16 \mathrm{~S}$ rRNA gene copy number were determined as above.

\section{Additional files}

Additional file 1: Table S1. Sequences of hydroxylase a-subunits of soluble diiron monooxygenases used in the design of isoA primers. Table S2. Primers used in this study targeting the isoA gene. Table S3. Combinations of isoA primers tested in this study. Table S4. Control strains used in this study to validate the iso A gene primers isoA14F and isoA511R. Table S5. Environmental samples used in this study. Table S7. Alpha diversity of enriched environmental samples subjected to iso A amplicon sequencing. Figure S1. Alignment of IsoA sequences from representative isoprenedegrading bacteria and position of the new isoA primers. Figure S2. Preliminary validation of isoA primers. Figure S3. Diversity and abundance of Operational Taxonomic Units obtained by amplicon sequencing from enriched environmental samples. Figure S4. Calibration curve for isoA qPCR assays. Figure S5. Relative abundance of isoprene degraders in enriched environmental samples estimated by qPCR. (DOCX $920 \mathrm{~kb}$ )

Additional file 2: Table S6. Operational taxonomic units (OTUs) retrieved from enriched environmental samples targeting isoA. (XLSX 22 kb)

\section{Acknowledgements}

We thank Elizabeth Wellington and lan Lidbury from the University of Warwick for importing soils from Malaysia to their laboratory and extracting DNA. We also thank Mohd Shahrul Mohd Nadzir from the National University of Malaysia for providing oil palm leaves and soil samples. We thank Nick Coleman, Scott Ensign and Greg Whited for providing bacterial strains (Mycobacterium chubuense NBB4, Xanthobacter autotrophicus Py2 and Pseudomonas mendocina KR1, respectively) to validate the isoA probes. We thank Paul Wilmes for advice on isoA amplicon sequencing analysis. We thank Andrew Crombie and Jonathan Todd for insightful comments on the manuscript and Robin Dawson, Colin Lockwood, Simone Payne and Leanne Sims for useful scientific discussions.

\section{Funding}

The work on this project was funded through an ERC advanced grant to J.C.M. (694578-IsoMet), Natural Environment Research Council (NERC) grants to J.C.M. (NE/J009725/1) and T.J.M. (NE/J009555/1), a Colombian Government Scholarship (No. 646, Colciencias/Newton Fund (2014)) to NLLM and the Earth and Life Systems Alliance (ELSA) at the University of East Anglia. 


\section{Availability of data and materials}

is $\mathrm{A}$ amplicon sequencing data generated in this study were deposited to the sequence read archives (SRA) under Bioproject PRJNA272922 (Biosamples SAMN10345540-SAMN10345550). Clone library sequence data were deposited to NCBI Genbank under accession numbers MK176357 to MK176478.

\section{Authors' contributions \\ OCF, TJM, NLLM and JCM planned the experiments. OCF, LG and NLLM carried out the experimental work and analysed results. MFUH planned and analysed GPCR experiments. JRG conducted is $\mathrm{A}$ amplicon sequencing analysis. OCF and JCM wrote the manuscript with contributions from all authors. All authors read and approved the manuscript before submission.}

\section{Ethics approval and consent to participate}

Not applicable.

\section{Consent for publication}

Not applicable.

\section{Competing interests}

The authors declare that they have no competing interests.

\section{Publisher's Note}

Springer Nature remains neutral with regard to jurisdictional claims in published maps and institutional affiliations.

\section{Author details}

'School of Environmental Sciences, University of East Anglia, Norwich Research Park, Norwich NR4 7TJ, UK. ${ }^{2}$ Luxembourg Centre for Systems Biomedicine, University of Luxembourg, Esch-sur-Alzette, Luxembourg. ${ }^{3}$ School of Biological Sciences, University of Essex, Colchester, UK.

\section{Received: 12 September 2018 Accepted: 25 November 2018} Published online: 07 December 2018

\section{References}

1. Atkinson R, Arey J. Gas-phase tropospheric chemistry of biogenic volatile organic compounds: a review. Atmos Environ. 2003;37(s2):197-219.

2. Guenther AB, Jiang X, Heald CL, Sakulyanontvittaya T, Duhl T, Emmons LK, Wang $X$. The model of emissions of gases and aerosols from nature version 2.1 (MEGAN2.1): an extended and updated framework for modeling biogenic emissions. Geosci Model Dev. 2012;5:1471-92.

3. Pacifico F, Harrison SP, Jones CD, Sitch S. Isoprene emissions and climate. Atmos Environ. 2009;43:6121-35.

4. Collins WJ, Derwent RG, Johnson CE, Stevenson DS. The oxidation of organic compounds in the troposphere and their global warming potentials. Clim Chang. 2002;52:453-79.

5. Folberth GA, Hauglustaine DA, Lathière J, Brocheton F. Interactive chemistry in the Laboratoire de Météorologie Dynamique general circulation model: model description and impact analysis of biogenic hydrocarbons on tropospheric chemistry. Atmos Chem Phys. 2006;6:2273-319.

6. Ashworth $\mathrm{K}$, Wild O, Hewitt CN. Impacts of biofuel cultivation on mortality and crop yields. Nat Clim Change. 2013;3:492-6.

7. Carlton AG, Wiedinmyer $C$, Kroll JH. A review of secondary organic aerosol (SOA) formation from isoprene. Atmos Chem Phys. 2009;9:4987-5005.

8. Fiore AM, Naik V, Spracklen DV, Steiner A, Unger N, Prather M, et al. Global air quality and climate. Chem Soc Rev. 2012;41:6663-83.

9. Sharkey TD, Wiberley AE, Donohue AR. Isoprene emission from plants: why and how. Ann Bot. 2008;101:5-18.

10. Bäck J, Aaltonen H, Hellén H, Kajos MK, Patokoski J, Taipale R, et al. Variable emissions of microbial volatile organic compounds (MVOCs) from rootassociated fungi isolated from scots pine. Atmos Environ. 2010;44:3651-9.

11. Dani SKG, Benavides AMS, Michelozzi M, Peluso G, Torzillo G, Loreto F. Relationship between isoprene emission and photosynthesis in diatoms, and its implications for global marine isoprene estimates. Mar Chem. 2017; 189:17-24.

12. Exton DA, Suggett DJ, McGenity TJ, Steinke M. Chlorophyll-normalized isoprene production in laboratory cultures of marine microalgae and implications for global models. Limnol Oceanogr. 2013;58:1301-11.

13. Fall R, Copley SD. Bacterial sources and sinks of isoprene, a reactive atmospheric hydrocarbon. Environ Microbiol. 2000;2:123-30.
14. Kuzma J, Nemecek-Marshall M, Pollock WH, Fall R. Bacteria produce the volatile hydrocarbon isoprene. Curr Microbiol. 1995;30:97-103.

15. McGenity TJ, Crombie AT, Murrell JC. Microbial cycling of isoprene, the most abundantly produced biological volatile organic compound on earth. ISME J. 2018;12:931-41.

16. Shaw SL, Gantt B, Meskhidze N. Production and emissions of marine isoprene and monoterpenes: a review. Adv Meterol. 2010;2010:408696. https://doi.org/10.1155/2010/408696.

17. Steinke M, Hodapp B, Subhan R, Bell TG, Martin-Creuzburg D. Flux of the biogenic volatiles isoprene and dimethyl sulphide from an oligotrophic lake. Sci Rep. 2018;8:630.

18. Morais ARC, Dworakowska S, Reis A, Gouveia L, Matos CT, Bogdal D, et al. Chemical and biological-based isoprene production: green metrics. Catal Today. 2015;239:38-43.

19. Logan BA, Monson RK, Potosnak MJ. Biochemistry and physiology of foliar isoprene production. Trends Plant Sci. 2000;5:477-81.

20. Zeinali N, Altarawneh M, Li D, Al-Nu'Airat J, Dlugogorski BZ. New mechanistic insights: why do plants produce isoprene? ACS Omega. 2016;1: 220-5.

21. Loivamäki M, Mumm R, Dicke M, Schnitzler JP. Isoprene interferes with the attraction of bodyguards by herbaceous plants. Proc Natl Acad Sci. 2005; 105:17430-5.

22. Sanadze GA. Biogenic isoprene emission as expression of dissipativity, a fundamental cell property. Russ J Plant Physiol. 2017;64:133-40.

23. Loreto F, Ciccioli P, Brancaleoni E, Valentini R, De Lillis M, Csiky O, et al. A hypothesis on the evolution of isoprenoid emission by oaks based on the correlation between emission type and Quercus taxonomoy. Oeacologia. 1998;115:17430-5.

24. Monson RK, Jones RT, Rosenstiel TN, Schnitzler JP. Why only some plants emit isoprene. Plant Cell Environ. 2013;36:503-16.

25. Sharkey TD. Is it useful to ask why plants emit isoprene? Plant Cell Environ. 2013;36:517-20

26. Greenberg JP, Guenther A, Zimmerman P, Baugh W, Geron C, Davis K, et al. Tethered balloon measurements of biogenic VOCs in the atmospheric boundary layer. Atmos Environ. 1999;33:855-67.

27. Wiedinmyer C, Greenberg J, Guenther A, Hopkins B, Baker K, Geron C, et al. Ozarks isoprene experiment (OZIE): measurements and modeling of the "isoprene volcano.". J Geophys Res-Atmos. 2005;110:1-17.

28. Cleveland CC, Yavitt JB. Microbial consumption of atmospheric isoprene in a temperate forest soil. Appl Env Microbiol. 1998;64:172-7.

29. Gray $\mathrm{CM}$, Helmig D, Fierer N. Bacteria and fungi associated with isoprene consumption in soil. Elem Sci Anth. 2015;3:000053.

30. Pegoraro E, Abrell L, Van Haren J, Barron-Gafford G, Grieve KA, Malhi Y, et al. The effect of elevated atmospheric $\mathrm{CO}_{2}$ and drought on sources and sinks of isoprene in a temperate and tropical rainforest mesocosm. Glob Change Biol. 2005;11:1234-46.

31. Acuña Alvarez LA, Exton DA, Timmis KN, Suggett DJ, McGenity TJ. Characterization of marine isoprene-degrading communities. Environ Microbiol. 2009;11:3280-91.

32. van Hylckama Vlieg JET, Kingma J, van den Wijngaard AJ, Janssen DB. A glutathione S-transferase with activity towards cis-1, 2-dichloroepoxyethane is involved in isoprene utilization by Rhodococcus sp. strain AD45. Appl Environ Microbiol. 1998;64:2800-5.

33. van Hylckama Vlieg JET, Kingma J, Kruizinga W, Janssen DB. Purification of a glutathione S-transferase and a conjugate-specific dehydrogenase involved in isoprene metabolism in Rhodococcus sp. strain AD45. J Bacteriol. 1999; 181:2094-101.

34. Crombie AT, Khawand ME, Rhodius VA, Fengler KA, Miller MC, Whited GM, et al. Regulation of plasmid-encoded isoprene metabolism in Rhodococcus, a representative of an important link in the global isoprene cycle. Environ Microbiol. 2015;17:3314-29.

35. Crombie AT, Emery H, McGenity TJ, Murrell JC. Draft genome sequences of three terrestrial isoprene-degrading Rhodococcus strains. Genome Announc. 2017:5:e01256-17.

36. El Khawand M, Crombie AT, Johnston A, Vavlline DV, MCAuliffe JC, Latone JA, et al. Isolation of isoprene degrading bacteria from soils, development of isoA gene probes and identification of the active isoprene-degrading soil community using DNA-stable isotope probing. Environ Microbiol. 2016;18:2743-53.

37. Johnston A, Crombie AT, Khawand ME, Sims L, Whited GM, McGenity TJ, et al. Identification and characterisation of isoprene-degrading bacteria in an estuarine environment. Environ Microbiol. 2017;19:3526-37. 
38. Larke-Mejía NL. Microbial ecology of isoprene degraders in the terrestrial environment. PhD thesis. Norwich, UK: School of Environmental Sciences, University of East Anglia; 2018.

39. van Hylckama Vlieg JET, Leemhuis $H$, Spelberg JHL, Janssen DB. Characterisation of the gene cluster involved in isoprene metabolism in Rhodococcus sp. strain AD45. J Bacteriol. 2000;182:1956-63.

40. Crombie AT, Mejía-Florez NL, McGenity TJ, Murrell JC. Genetics and ecology of isoprene degradation. In: Rojo F, editor. Aerobic utilization of hydrocarbons, oils and lipids. Cham: Springer International Publishing; 2018. p. $1-15$.

41. Coleman NV, Bui NB, Holmes AJ. Soluble di-iron monooxygenase gene diversity in soils, sediments and ethene enrichments. Environ Microbiol. 2006;8:1228-39.

42. Leahy JG, Batchelor PJ, Morcomb SM. Evolution of the soluble diron monooxygenases. FEMS Microbiol Rev. 2003;27:449-79.

43. Dumont MG, Murrell JC. Community-level analysis: key genes of aerobic methane oxidation. Methods Enzymol. 2005;397:413-27.

44. McDonald IR, Kenna EM, Murrell JC. Detection of methanotrophic bacteria in environmental samples with the PCR. Appl Environ Microbiol. 1995;61:116-21.

45. McDonald IR, Bodrossy L, Chen Y, Murrell JC. Molecular ecology techniques for the study of aerobic methanotrophs. Appl Environ Microbiol. 2008;74:1305-15.

46. Farhan UI Haque M, Crombie AT, Ensminger SA, Baciu C, Murrell JC. Facultative methanotrophs are abundant at terrestrial natural gas seeps. Microbiome. 2018;6:118.

47. Altschul SF, Gish W, Miller W, Myers EW, Lipman DJ. Basic local alignment search tool. J Mol Biol. 1990;215:403-10.

48. Lee J, Lee CS, Hugunin KM, Maute CJ, Dysko RC. Bacteria from drinking water supply and their fate in gastrointestinal tracts of germ-free mice: a phylogenetic comparison study. Water Res. 2010;44:5050-8.

49. Willems A, Mergaert J, Swings J, Genus X. Variovorax. In: Brenner DJ, Krieg NR, Staley JT, Garrity GM, editors. Bergey's manual of systematic bacteriology. 2nd edition, volume 2: the Proteobacteria. Part C: the Alpha-, Beta-, Delta and Epsilonproteobacteria. New York: Springer; 2005. p. 732-5.

50. Woo HL, Hazen TC, Simmons BA, DeAngelis KM. Enzyme activities of aerobic lignocellulolytic bacteria isolated from wet tropical forest soils. Syst Appl Microbiol. 2014;37:60-7.

51. Lambais MR, Crowley DE, Cury JC, Büll RC, Rodrigues RR. Bacterial diversity in tree canopies of the Atlantic forest. Science. 2006:312:1917.

52. Vorholt JA. Microbial life in the phyllosphere. Nat Rev Microbiol. 2012;10: 828-40

53. Bodenhausen N, Horton MW, Bergelson J. Bacterial communities associated with the leaves and roots of Arabidopsis thaliana. PLoS One. 2013;8:e56329.

54. Han Jl, Choi HK, Lee SW, Orwin PM, Kim J, Laroe SL, et al. Complete genome sequence of the metabolically versatile plant growth-promoting endophyte Variovorax paradoxus S110. J Bacteriol. 2011;193:1183-90.

55. Satola B, Wübbeler JH, Steinbüchel A. Metabolic characteristics of the species Variovorax paradoxus. Appl Microbiol Biotechnol. 2013;97:541-60.

56. Baik KS, Choe HN, Park SC, Hwang YM, Kim EM, Park C, et al. Sphingopyxis rigui sp. nov. and Sphingopyxis wooponensis sp. nov., isolated from wetland freshwater, and emended description of the genus Sphingopyxis. Int I Syst Evol Microbiol. 2013;63:1297-303.

57. Choi JH, Kim MS, Jung MJ, Rosh SW, Shin KD, Bae JW. Sphingopyxis soli sp. nov., isolated from landfill soil. Int J Syst Evol Microbiol. 2010;60:1682-6.

58. Kim BS, Lim YW, Chun J. Sphingopyxis marina sp. nov. and Sphingopyxis litoralis sp. nov., isolated from seawater. Int J Syst Evol Microbiol. 2008:58:2415-9.

59. Srinivasan S, Kim MK, Sathiyaraj G, Veena V, Mahalakshmi M, Kalaiselvi S, et al. Sphingopyxis panaciterrulae sp. nov., isolated from a ginseng field. Int J Syst Evol Microbiol. 2010;60:2358-63.

60. Callahan BJ, McMurdie PJ, Rosen MJ, Han AW, Johnson AJ, Holmes SP. DADA2: high-resolution sample inference from Illumina amplicon data. Nat Methods. 2016;13:581-3.

61. Beckers B, Op De Beeck M, Weyens N, Boerjan W, Vangronsveld J. Structural variability and niche differentiation in the rhizosphere and endosphere bacterial microbiome of field-grown poplar trees. Microbiome. 2017:5:25.

62. Guenther A, Zimmerman P, Wildermuth M. Natural volatile organic compound emission rates estimates for US woodland landscapes. Atmos Environ. 1994;28:1197-210.

63. Kesselmeier J, Staudt M. Biogenic volatile organic compounds (VOC): an overview on emission, physiology and ecology. J Atmos Chem. 1999;33:23-88.
64. Bittar TB, Pound P, Whitetree A, Moore LD, Van Stan JT. Estimation of throughfall and stemflow bacterial flux in a subtropical oak-cedar forest. Geophys Res Lett. 2018;45:1410-8.

65. Ciullo PA, Hewitt N. The rubber formulary. New York: Elsevier Science; 1999.

66. Shuttleworth MJ, Watson AA. Synthetic polyisoprene rubbers. In: Whelan A, Lee KS, editors. Developments in rubber technology-2: synthetic rubbers. Dordrecht: Springer Netherlands; 1981. p. 233-67.

67. Linos A, Steinbüchel A. Biodegradation of natural and synthetic rubbers. In: Koyama T, Steinbüchel A, editors. Biopolymers-biology, chemistry, biotechnology, applications, vol. 2 (Polyisoprenoids), 1st ed. Weinhem: Wiley-VCH; 2001. p. 321-59.

68. Shah AA, Hasan F, Shah N, Kanwal N, Zeb S. Biodegradation of natural and synthetic rubbers: a review. Int Biodeterior Biodegrad. 2013;83:145-57.

69. Andler R, Hiessl S, Yücel O, Tesch M, Steinbüchel A. Cleavage of poly(cis-1,4isoprene) rubber as solid substrate by culture of Gordonia polyisoprenivorans. New Biotechnol. 2018;44:6-12.

70. Imai S, Ichikawa K, Muramatsu Y, Kasai D, Masai E, Fukuda M. Isolation and characterisation of Streptomyces, Actinoplanes and Methylibium strains that are involved in degradation of natural rubber and synthetic poly(cis-1,4isoprene). Enzym Microb Technol. 2011;49:526-31.

71. Jendrossek D, Tomasi G, Kroppenstedt RM. Bacterial degradation of natural rubber: a privilege of actinomycetes? FEMS Microbiol Lett. 1997;150:179-88.

72. Linos A, Berekaa MM, Reichelt R, Keller U, Schmitt J, Flemming HS, et al. Biodegradation of cis-1,4-polyisoprene rubbers by distinct actinomycetes: microbial strategies and detailed surface analysis. Appl Environ Microbiol. 2000:66:1639-45.

73. Bode HB, Zeeck A, Pluckhahn K, Jendrossek D. Physiological and chemical investigations into microbial degradation of synthetic poly(cis-1,4-isoprene). Appl Environ Microbiol. 2000;66:3680-5.

74. Srivastva N, Shukla AK, Singh RS, Upadhyay SN, Dubey SK. Characterisation of bacterial isolates from rubber dump site and their use in biodegradation of isoprene in batch and continuous bioreactors. Bioresour Technol. 2015; 188:84-91.

75. Booge D, Schlundt C, Bracher A, Endres S, Zäncker B, Marandino CA. Marine isoprene production and consumption in the mixed layer of the surface ocean - a field study over two oceanic regions. Biogeosciences. 2018;15:649-67.

76. Booge D, Marandino C, Schlundt C, Palmer PI, Saltzman ES, Wallace DW Can simple models predict large scale surface ocean isoprene concentrations? Atmos Chem Phys. 2016;16:11807-21.

77. Moore RM, Wang L. The influence of iron fertilisation on the fluxes of methyl halides and isoprene from ocean to atmosphere in the SERIES experiment. Deep-Sea Res Pt II. 2006;53:2938-409.

78. Palmer PI, Shaw SL. Quantifying global marine isoprene fluxes using MODIS chlorophyll observations. Geophys Res Lett. 2005;32:L09805.

79. Dorn E, Hellwig M, Reineke W, Knackmuss HJ. Isolation and characterization of a 3-chlorobenzoate degrading pseudomonad. Arch Microbiol. 1974;99:61-70.

80. Baumann P, Baumann L. The marine gram-negative eubacteria: genera Photobacterium, Beneckea, Alteromonas, Pseudomonas and Alcaligenes. In: Starr MP, Stolp H, Trüper HG, Balows A, Schlegel HG, editors. The prokaryotes: a handbook on habitats, isolation and identification of Bacteria. New York: Springer-Verlag; 1981. p. 1302-31

81. Lane DJ. 16S/23S rRNA sequencing. In: Stackebrandt E, Goodfellow M, editors. Nucleic acid techniques in bacterial systematics. Chichester: John Wiley \& Sons; 1991. p. 115-75.

82. Kumar S, Stecher G, Tamura K. MEGA7: molecular evolutionary genetics analysis version 7.0 for bigger datasets. Mol Biol Evol. 2016;33:1870-4.

\section{Ready to submit your research? Choose BMC and benefit from:}

- fast, convenient online submission

- thorough peer review by experienced researchers in your field

- rapid publication on acceptance

- support for research data, including large and complex data types

- gold Open Access which fosters wider collaboration and increased citations

- maximum visibility for your research: over $100 \mathrm{M}$ website views per year

At $\mathrm{BMC}$, research is always in progress.

Learn more biomedcentral.com/submissions 